\title{
THE ETIOLOGY OF HYPEROSTOSIS CRANII (METABOLIC CRANIOPATHY)
}

\author{
A Clinical Study \\ J. E. Caughey, Dunedin, New Zealand \\ Associate Professor in Neurology, Otago Medical School, New Zealand
}

Hyperostosis cranii or metabolic craniopathy was first recognised as an essential part of Morgagni's syndrome of virilism, obesity and hyperostosis frontalis. It is a syndrome of uncertain origin which was believed to occur almost exclusively in middle aged and elderly women. More recently it has been shown to occur in younger women and rarely to occur in men.

The syndrome is characterised by thickening of the inner table of the skull, more usually in the frontal region, but it may also occur over other parts of the skull, including the basal bones and the orbital plate. There may be generalised thickening of the whole calvarium. In the frontal region especially, the inner surface of the skull may become nodular and it may attain a depth of more than a centimetre. This thickening consists of spongy bone containing large numbers of osteoblasts and the underlying dura is usually thickened and adherent.

\section{NOMENCLATURE}

Hyperostosis cranii has usually been referred to as hyperostosis frontalis interna, which is a part of the Morgagni syndrome. The Stewart-Morel syndrome is the name introduced by Schiff and Trelles (1932) for that group of cases in which changes in the mental state are found in association with obesity, virilism and hyperostosis frontalis interna. It later came to be recognised that the skull changes occur apart from obesity and virilism and that they may involve areas of the skull other than the frontal bones. This led to the introduction of the name metabolic craniopathy by Moore (1936a). In his recent monograph on the subject, Moore (1955) used the title hyperostosis cranii, which name will be used throughout this paper.

\section{TYPES OF HYPEROSTOSIS CRANII}

In a study of 6,650 skull radiographs over a period of twenty-four years Moore (1936b) identified four types of thickening of the calvarium, which he named hyperostosis frontalis interna, nebula frontalis, hyperostosis calvariae diffusa, and hyperostosis fronto-parietalis (Figs. 1 to 3).

Hyperostosis frontalis interna-This is the most characteristic type and involves the frontal bones, with deposits of bone on the inner tables.

Nebula frontalis - In this the change in the calvarium consists of a triangular or ellipsoid area of increased density located in the frontal region and extending downwards from a base on the sagittal plane.

Hyperostosis calvariae diffusa-In this third type there is generalised thickening of the calvarium with an increase of density of the diplöe. The basal bones also may be involved. Hyperostosis fronto-parietalis-In this form, which is probably a stage in the development of hyperostosis calvariae diffusa, there is thickening of the inner tables of the frontal and the parietal bones.

It is generally accepted that these four types are expressions of the same entity. Hence the name hyperostosis cranii may be used to cover all four.

Moore (1936b) found the incidence of these types of hyperostosis in 6,650 skull films as follows: hyperostosis frontalis interna 1.44 per cent; nebula frontalis 1.14 per cent; hyperostosis 


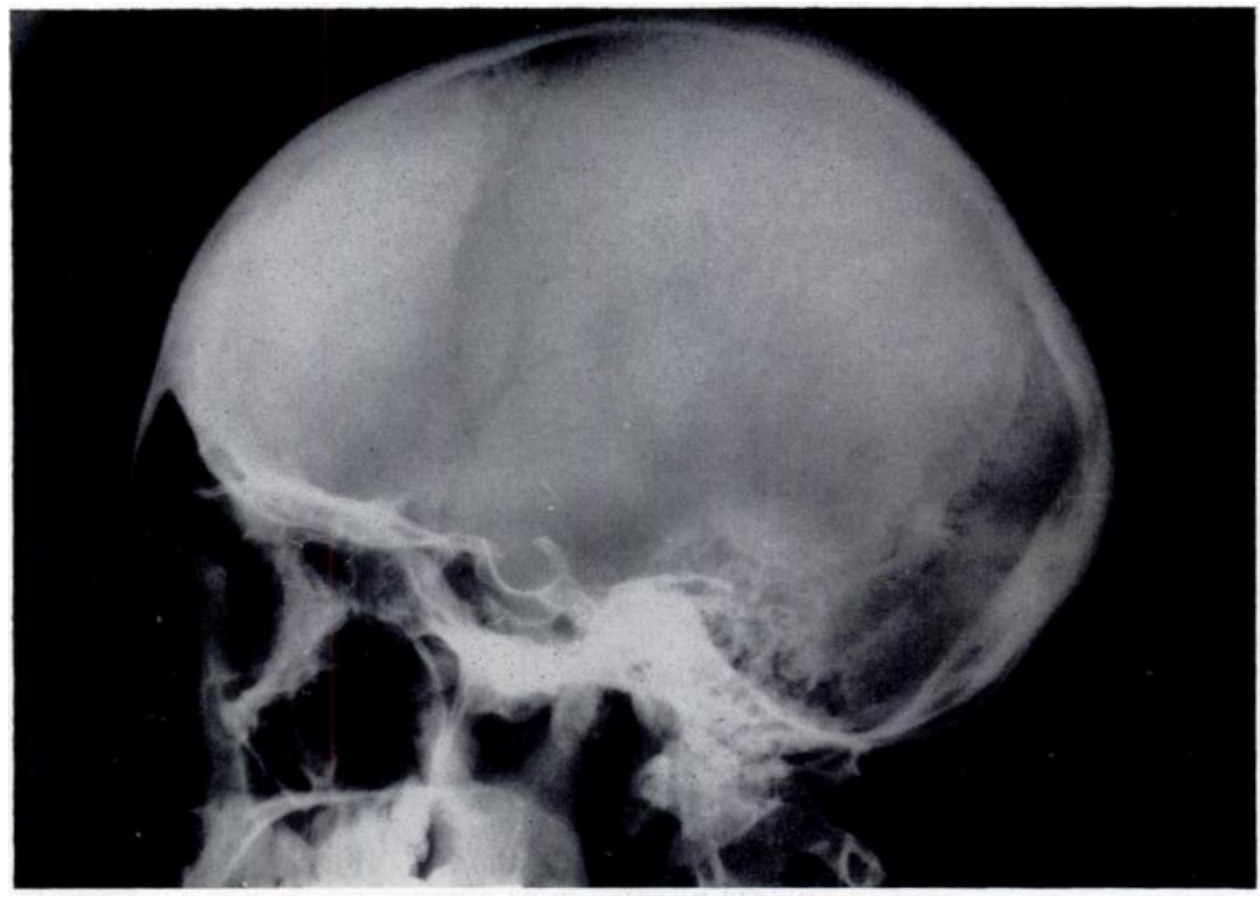

Fig. 1

Nebula frontalis or early hyperostosis frontalis interna.

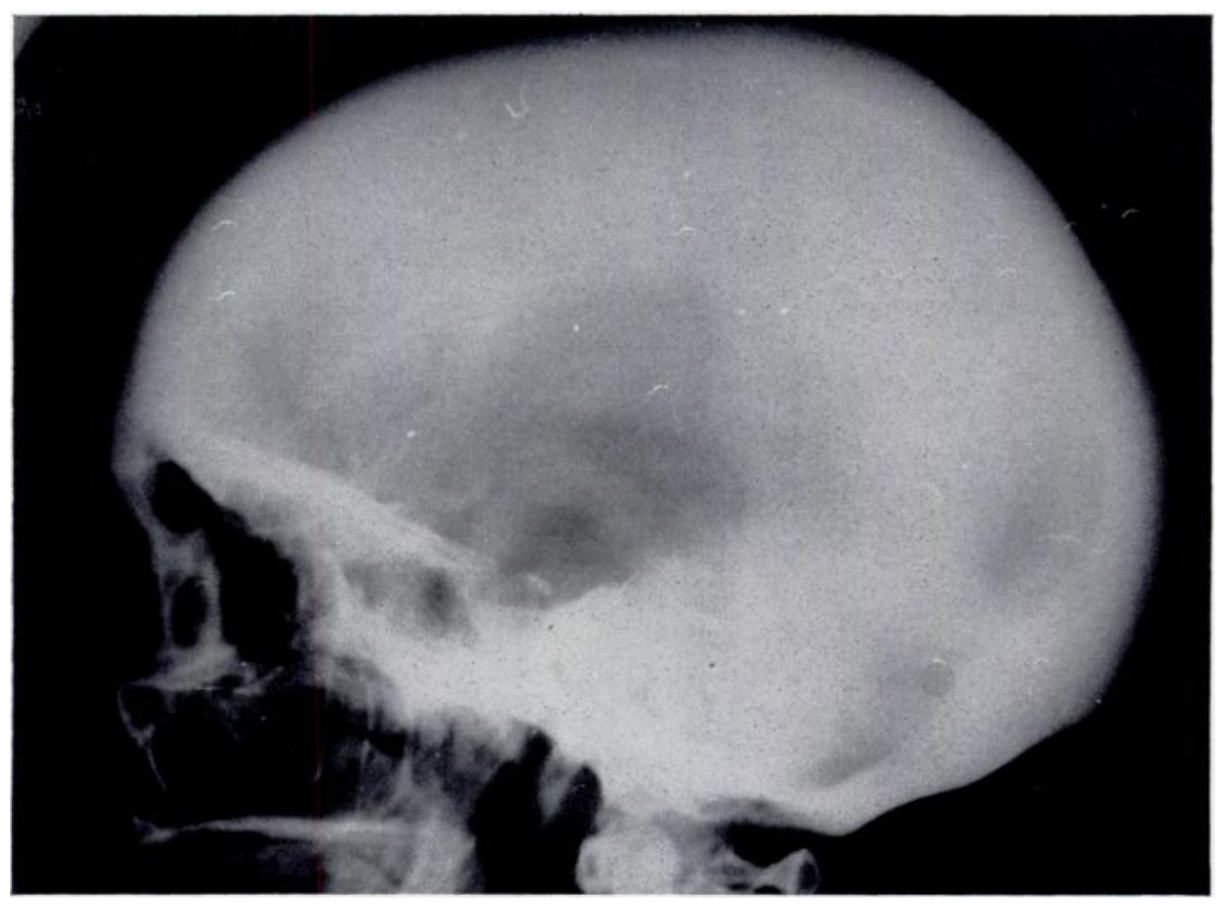

Fig. 2

Hyperostosis calvariae diffusa. 
calvariae diffusa 0.6 per cent; hyperostosis fronto-parietalis 0.3 per cent. The total incidence of hyperostosis was 3.5 per cent in 6,650 skulls.

In an examination of 582 skulls in a department of anatomy, Moore (1936b) found forty-six with hyperostosis cranii (hyperostosis frontalis interna, twenty-nine cases; nebula frontalis, fourteen cases; hyperostosis calvariae diffusa, three cases).

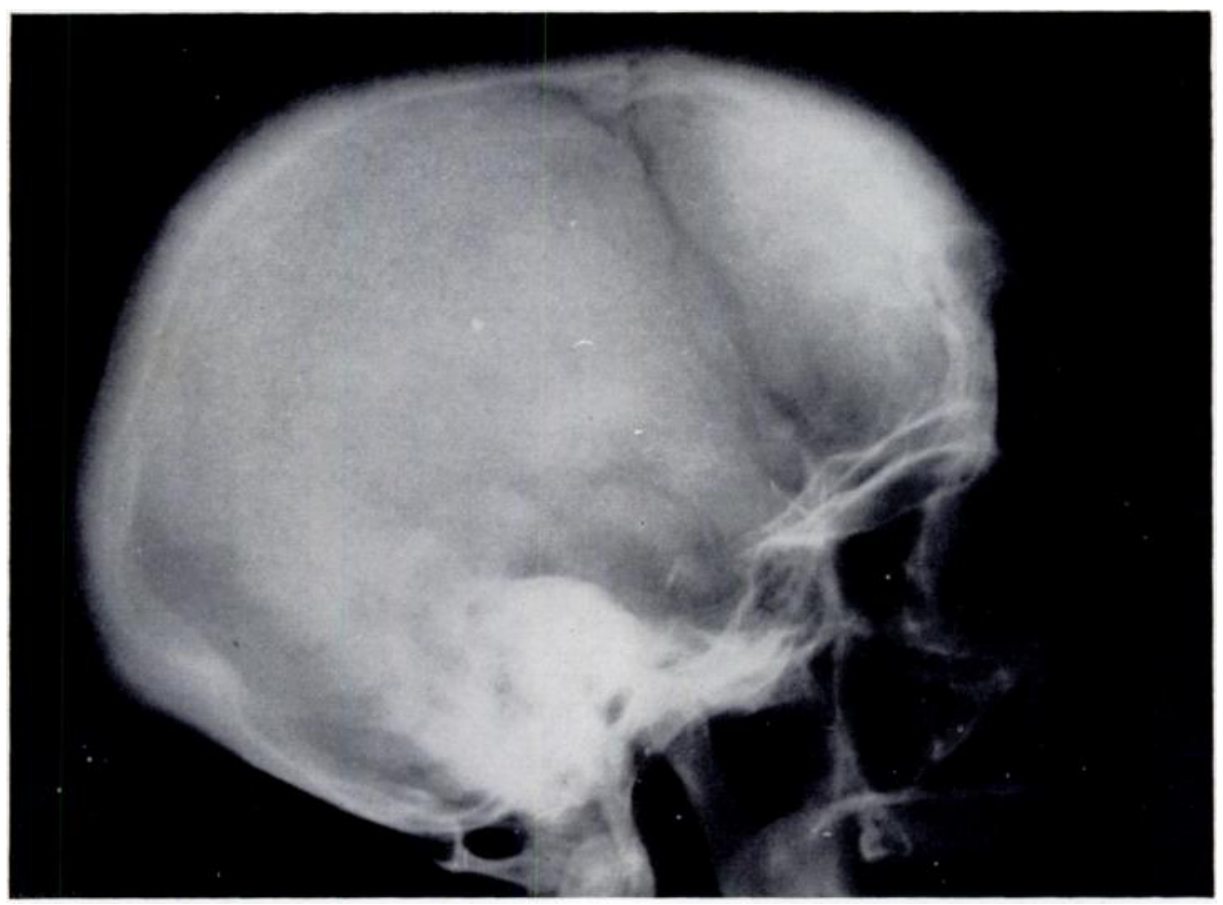

Fig. 3

Hyperostosis fronto-parietalis.

\section{AGE AND SEX DISTRIBUTION}

It can be said that the incidence of hyperostosis cranii among the general population is unknown. On the other hand, most workers who have studied this syndrome have noted the overwhelming occurrence among women. Henschen (1949) found that 99 per cent of his cases were in women, and Moore (1935) 98.2 per cent. The only exception to this was a small group of fifteen patients with dystrophia myotonica and hyperostosis cranii reported by Caughey (1952a), in which the distribution was ten males to five females.

The most common age at which the syndrome occurs is in the fourth, fifth and sixth decades. Recent studies by Moore (1955) of a large group of healthy young women revealed that 14 per cent had some slight degree of hyperostosis cranii.

\section{SYNDROMES ASSOCIATED WITH HYPEROSTOSIS CRANII}

Hyperostosis cranii accompanies several clinical states.

Morgagni's syndrome - In his original report, Morgagni (1765) described the necropsy of an obese, virile, hirsute woman, with an overgrowth of bone in the inner aspect of the frontal bones, and Henschen (1936) coined the term Morgagni's syndrome for cases with this triad. Stewart-Morel syndrome (Morgagni-Morel syndrome)-Shattock (1913) described thickening of the calvarium in the insane, and Stewart (1928) wrote on the same topic. Morel (1930) first diagnosed a case before death. Schiff and Trelles (1932) introduced the title of StewartMorel syndrome, and Calame (1951) used the name Morgagni-Morel syndrome to designate 
those examples of the Morgagni syndrome with associated disturbances in the mental state. Hyperostosis cranii with acromegaly - A general thickening of the calvarium and other evidence of hyperostosis cranii have long been recognised in patients with acromegaly. It is noteworthy too that marked degrees of hyperostosis cranii in acromegaly are most usually seen in women. In Moore's (1955) study of forty-eight patients with acromegaly and acromegaloid cases, nine had hyperostosis cranii and of these eight were women.

Troell (1938) and Junet (1938) first reported cases of acromegaly with thyrotoxicosis. In all, eleven cases of this type have been described. All were in acromegalic women, ten of whom had enlarged nodular thyroids. Seven had diabetes and all but one had metabolic craniopathy with thickening of the calvarium. Three had hyperostosis frontalis interna.

Dystrophia myotonica and hyperostosis cranii-This received mention by Rouquè (1931) and Fagin (1946). Caughey and Brown (1950) discussed this aspect of the disorder and suggested that the skull changes occurred so often that they should come to be recognised as one of the variable features of the disorder. Later, Caughey (1952a and 1952b) reported fifteen cases of dystrophia myotonica with skull changes, and with a preponderance in men as stated above. Senile hyperostosis cranii-In Moore's (1955) valuable statistical study, the highest incidence of hyperostosis cranii was in the fifth and sixth decades; there remained a considerable group in the seventh and eighth decades which on occasions have been called the senile group of hyperostosis cranii.

\section{ETIOLOGICAL CONCEPTS}

Various concepts of the disease have been proposed and relevant studies have been reviewed by Knies and Le Fever (1941). Syphilis has been suggested by Marchand and Bauer (1925). Bonnamour and Jamin (1926) and Picard (1926) suggested that it was an aberrant form of Paget's disease. Caughey, Gwynne and Jefferson (1957) recently reported a family with familial Paget's disease and dystrophia myotonica which was considered to be coincidental. Knaggs (1925) supported the suggestion of an inflammatory background. Injury as a mechanical cause of congestion has been invoked but has been dismissed for lack of evidence. Morel (1930) considered that the syndrome was the result of generalised calcium dysmetabolism and suggested that the frontal region might be conditioned by the tension of adherent dura. Naito and Schüller (1923) and Dressler (1927) suggested that the bony changes of metabolic craniopathy might be compensatory to senile changes in the brain with atrophy and subsequent thickening of the inner tables.

A possible relationship to puerperal osteophytes has been suggested by various authors. Greig (1928) considered that if a mother does not nurse her baby there is an excess of calcium circulating in the blood which might favour its deposition in certain areas. Against these suggestions, Moore (1936b) showed that 50 per cent of women with hyperostosis cranii have never been pregnant. Carr (1936) noted an abnormality of menstrual function in 76.4 per cent of a rather small series. The possibility of a relationship to the menopause has been postulated by many but recently considered unlikely in view of the occurrence in young women.

More recent studies focus attention on the endocrine system. Moore stated: "In general terms the syndrome is the expression of an uncontrolled growth stimulus common to both sexes. Because the process of reproduction is more dynamic in the female than the male the former are more subject to the condition. There is no evidence of general influence on all tissues comparable with acromegaly."

\section{PURPOSE OF THIS STUDY}

Moore (1955) stated that the cause of hyperostosis cranii resides in both sexes. In previous studies of the syndrome, as seen in dystrophia myotonica, it is apparent from a small but convincing series of cases that hyperostosis cranii is one of the variable and common features of the disorder and that it occurs in males and females alike. In other series of cases of 
hyperostosis cranii of all types quoted by Henschen (1949) and by Moore (1955), there has been an overwhelming preponderance of female cases. Thus it seems possible that the key to the problem may be found in a study of dystrophia myotonica.

The case material is drawn from a personal group of fifty cases of dystrophia myotonica with the fully developed disorder. A series of reports has already been published dealing with the cataract, the endocrine features of the disease, the bone changes in the skull, unilateral elevation of the diaphragm, congenital physical defects, and cardiac changes; and recently the family with familial Paget's disease and dystrophia myotonica has been reported.

In this present publication the endocrine changes and the hyperostosis cranii will be reviewed and an attempt will be made to discover etiological factors that could account for the hyperostosis cranii.

\section{DYSTROPHIA MYOTONICA}

Dystrophia myotonica is a heredo-familial disorder which is transmitted by male and female alike and by both normal and affected individuals. When the mutation first makes its appearance in a family, cataract is the usual presenting feature. In subsequent generations the cataract usually occurs at an earlier age and is associated with the other features of the fully developed disorder such as muscle wasting, myotonia, loss of reflexes and certain endocrinological changes of which the most constant are gonadal atrophy, frontal baldness and hyperostosis cranii. The sex distribution of the disease is reported by most workers to be equal among males and females.

\section{ENDOCRINE CHANGES IN DYSTROPHIA MYOTONICA}

Early studies of the ductless glands by Wilson (1940) showed changes that were " too banal for any conclusions to be drawn." Adie and Greenfield (1923) described changes in the pituitary body and in the cortex of the suprarenal glands which " were beyond what is usual." Other endocrine glands were not described.

In an endocrine study of nine cases Caughey and Brown (1950) made an attempt to assess the endocrine changes (Appendix 1). The main conclusions were as follows.

Body growth-The skeletal proportions of these patients were within normal limits, the height and span being approximately equal, and the vertex-to-pubis measurements equal to the pubis-to-sole measurement. There was no radiological evidence of delay of epiphysial closure. These clinical observations, the previous history of the patients, and the endocrine studies which will be discussed later left little doubt that the hypogonadism was a post-puberal type. Hair growth-Frontal recession of head hair is well recognised in the disorder and in the series was apparent in all the male cases. Changes in body hair were variable. Two men showed scanty growth of facial hair. In four men the secondary sex hair was normal in amount and distribution.

General function-In all the patients in the series the onset of hypogonadism occurred some time after puberty, as was evident from the normal skeletal proportions, the normal development of secondary sex hair, the size of the genitalia, the normal voice, and the normal radiological appearance of the long bones and sinuses. Hypogonadism always begins some time after the onset of myotonia and wasting. One woman had noticed difficulty in relaxing her grip twelve years before, but had since given birth to three children. In the men the size of the penis was normal and the scrotum was well developed; the distribution of pubic hair was normal except in two, in whom it was of female distribution. The testes in five were soft, and the size of a small almond; in two they were normal. Normal testicular sensation was present. Potentia was much reduced, but still present, and occasional emissions occurred. The prostate was examined in four, and was small in each case. Examination of the semen of one patient failed to reveal active spermatozoa. Testicular biopsy was carried out in three patients in an advanced stage of the disease, and the following observations were made.

VOL. $40 \mathrm{~B}$, NO. 4, NOVEMBER 1958 
Case 1: Atrophy both of seminiferous and of interstitial elements was almost complete in both testes. The basement membranes of the seminiferous tubules persisted, but no spermatogenic or supporting cells were to be seen. A few vestigial Leydig cells were present. Case 8: In the specimen examined the seminiferous tubules had for the most part atrophied completely, the zones normally occupied by epithelial cells being filled by hyaline fibrous tissue. One or two tubules still contained spermatocytes with pyknotic nuclei, but there was no evidence of spermatogenesis. Interstitial cells were identified with difficulty and appeared degenerate. Case 9: Two pale grey portions of tissue of irregular contour were examined and found to consist of epididymal tubules and ducti efferentes. No spermatozoa were found in their lumina.

Gynaecomastia-Gynaecomastia was noted in one male patient only (Case 1), and followed treatment with testosterone, by injection and implant, for twelve months. The development of gynaecomastia in a proportion of eunuchoid males treated with testosterone was reported by McCullagh and Rossmiller (1941). Klinefelter, Reifenstein and Albright (1942) pointed out that the production of this kind of gynaecomastia depends on the presence of androgen and the absence of spermatogenesis, conditions which were both present in this patient. Two other male patients were treated with testosterone but did not develop gynaecomastia.

Follicle-stimulating hormone-The assay was made by the Klinefelter, Albright and Griswold (1943) method, using the enlargement of the immature mouse uterus as the end-point. A result was considered positive when the mouse uterus weighed 10 milligrams or more. Normal excretions by this method lie between 13 and 54 mouse units in twenty-four hours. Assays of the follicle-stimulating hormone were carried out on five of the patients, four male and one female. Three of the male patients (Cases 1, 8 and 9) had the fully developed syndrome with gonadal atrophy, and their urine excreted in twenty-four hours was positive to 96 and negative to 192 mouse units. The excretion in the patient in Case 7, who was past the menopause and who would normally be expected to have a high hormone value, was strongly positive to 96 mouse units. The patient in Case 3, who had no loss of libido or sexual power, and whose testicles and prostate gland appeared normal, excreted normal amounts of the hormone (positive to 26 mouse units in twenty-four hours, and negative to 54 ). In general, these results agree with those of Benda and Bixby (1947), who found in one of their patients an excretion of follicle-stimulating hormone positive to 96 and 192 mouse units, and reported high excretion in another.

TABLE I

Blood Electrolyte Levels

\begin{tabular}{|cccc|}
\hline $\begin{array}{c}\text { Case } \\
\text { number }\end{array}$ & $\begin{array}{c}\text { Plasma-chlorides } \\
\text { (as NaCl } \\
\text { milligrams/100 millilitres) } \\
(\text { Normal=570 to 620) }\end{array}$ & $\begin{array}{c}\text { Serum-sodium } \\
\text { (milligrams/100 millilitres) } \\
(\text { Normal =325 to 350) }\end{array}$ & $\begin{array}{c}\text { Serum-potassium } \\
\text { (milligrams/100 millilitres) } \\
\text { (Normal=16 to 20) }\end{array}$ \\
\hline 1 & 570,556 & 327 & 17 \\
3 & 580 & 342 & - \\
7 & 556 & 335 & - \\
8 & 600,590 & 332 & $17 \cdot 5$ \\
9 & 580,600 & 340 & 16 \\
\hline
\end{tabular}

Adrenal function-In no case was abnormal pigmentation apparent. Tests of adrenal function were divided into three categories: 1) electrolyte estimations, 2) tests of carbohydrate metabolism and 3) tests of 17-ketosteroid excretion. The plasma-chloride and serum-sodium were estimated in five patients, and the serum-potassium in three. The results were normal (Table I). 
The water excretion test (Robinson, Power and Kepler 1941) was performed on three patients. All had a delayed diuresis after the ingestion of a large volume of fluid, but the indices derived from applying the formula in the second part of the test were normal (Table II).

TABLE II

WATER EXCRETION TEST

\begin{tabular}{|c|c|c|c|}
\hline $\begin{array}{c}\text { Case } \\
\text { number }\end{array}$ & $\begin{array}{l}\text { Volume of } \\
\text { night urine } \\
\text { (millilitres) }\end{array}$ & $\begin{array}{l}\text { Greatest volume } \\
\text { of hourly urine } \\
\text { (millilitres) }\end{array}$ & Index \\
\hline 7 & 435 & 315 & 38 \\
\hline 8 & 300 & 210 & 35 \\
\hline 9 & 360 & 270 & 31 \\
\hline
\end{tabular}

TABLE III

Glucose Tolerance Test

\begin{tabular}{|c|c|c|c|c|c|c|}
\hline \multirow{2}{*}{$\begin{array}{c}\text { Case } \\
\text { number }\end{array}$} & \multicolumn{6}{|c|}{ Blood sugar (milligrams/100 millilitres) } \\
\hline & Fasting & $\frac{1}{2}$ hour & 1 hour & $1 \frac{1}{2}$ hours & 2 hours & $2 \frac{1}{2}$ hours \\
\hline 1 & $\left\{\begin{array}{l}98 \\
85\end{array}\right.$ & $\begin{array}{l}125 \\
112\end{array}$ & $\begin{array}{l}135 \\
120\end{array}$ & $\begin{array}{l}139 \\
140\end{array}$ & $\begin{array}{l}130 \\
134\end{array}$ & $\begin{array}{l}124 \\
118\end{array}$ \\
\hline 2 & 80 & 115 & 90 & 75 & 70 & - \\
\hline 3 & 83 & 140 & 96 & 69 & 72 & 82 \\
\hline 7 & 71 & 96 & 131 & 148 & 129 & - \\
\hline 8 & 65 & 120 & 135 & 130 & 85 & - \\
\hline 9 & 80 & 160 & 130 & 130 & 90 & - \\
\hline
\end{tabular}

TABLE IV

INSULIN TOLERANCE TEST

\begin{tabular}{|c|c|c|c|c|c|c|c|}
\hline \multirow[b]{2}{*}{$\begin{array}{c}\text { Case } \\
\text { number }\end{array}$} & \multicolumn{7}{|c|}{ Blood-sugar (per cent of fasting value) } \\
\hline & $\begin{array}{c}\text { Fasting } \\
\text { (milligrams/100 millilitres } \\
\text { in parentheses) }\end{array}$ & 20 minutes & 30 minutes & 45 minutes & 60 minutes & 90 minutes & 120 minutes \\
\hline 1 & $\left\{\begin{array}{l}100(106) \\
100(100)\end{array}\right.$ & $\begin{array}{l}64 \\
72\end{array}$ & $\begin{array}{l}58 \\
41\end{array}$ & $\begin{array}{l}48 \\
37\end{array}$ & $\begin{array}{l}72 \\
77\end{array}$ & $\begin{array}{r}83 \\
110\end{array}$ & $\begin{array}{r}92 \\
105\end{array}$ \\
\hline 2 & $100(76)$ & 80 & 60 & 66 & 68 & 102 & 105 \\
\hline 5 & $100(106)$ & 59 & 43 & 57 & 63 & 70 & 120 \\
\hline 7 & $100(70)$ & 71 & 55 & 70 & 73 & 105 & 117 \\
\hline 8 & $100(75)$ & 80 & 53 & 80 & 87 & 75 & 100 \\
\hline 9 & $100(90)$ & 72 & 50 & 78 & 84 & 89 & 90 \\
\hline
\end{tabular}

Adrenal cortical hormone function was assessed by the glucose tolerance test and the insulin sensitivity test. The standard two-hour tolerance test with $\mathbf{5 0}$ grammes of oral glucose was used. Insulin tolerance was tested by the method of Fraser, Albright and Smith (1941). Sugar determinations were made by the micro-method of Folin (1922) with capillary blood. The results are given in Tables III and IV, and on the whole are normal.

Vol. $40 \mathrm{~B}$, NO. 4, NOVEMBER 1958 
The level of neutral urinary 17-ketosteroids was determined by the Fraser, Forbes, Albright, Sulkowitch and Reifenstein (1941) method, in which spectrophotometric correction is made for extraneous colours. The results are given in Table $\mathrm{V}$, and are well below normal limits. Patients in whom the disease was advanced had excretions approaching those found in panhypopituitarism.

TABLE V

Urinary 17-Ketosteroid Determinations

\begin{tabular}{|c|c|}
\hline $\begin{array}{c}\text { Case } \\
\text { number }\end{array}$ & $\begin{array}{l}\text { 17-ketosteroid excretion } \\
\text { (milligrams in } 24 \text { hours) }\end{array}$ \\
\hline 1 & $1 \cdot 0,0 \cdot 4,1 \cdot 1,1 \cdot 3$ \\
\hline 2 & $2 \cdot 5,4 \cdot 5$ \\
\hline 3 & $4 \cdot 2,5 \cdot 5$ \\
\hline 4 & $2 \cdot 3$ \\
\hline 5 & $4 \cdot 8$ \\
\hline 6 & 1.7 \\
\hline 7 & 1.8 \\
\hline 8 & $1 \cdot 2$ \\
\hline 9 & $3 \cdot 1$ \\
\hline
\end{tabular}

Thyroid function-The basal metabolic rate and serum-cholesterol levels were estimated in seven patients (Table VI). Waring, Ravin and Walker (1940) reported, as a rule, low basal metabolic rates and normal cholesterol levels. Only two patients in the series had abnormally low basal metabolic rates, but raised cholesterol levels were found more frequently and appeared

TABLE VI

Basal Metabolic Rate and Serum Cholesterol

\begin{tabular}{|ccc|}
\hline $\begin{array}{c}\text { Case } \\
\text { number }\end{array}$ & $\begin{array}{c}\text { Basal metabolic rate } \\
\text { (per cent) }\end{array}$ & $\begin{array}{c}\text { Serum-cholesterol } \\
\text { (normal } 120-220 \text { milligrams/100 millilitres) }\end{array}$ \\
\hline 1 & $-34,-48$ & 335,360 \\
2 & $-12,-8$ & 180 \\
3 & $+38,+27$ & 210 \\
5 & - & 180 \\
6 & +10 & - \\
7 & -4 & 310 \\
8 & +9 & 200 \\
9 & -9 & 205,280 \\
\hline
\end{tabular}

to parallel the severity of the condition. The patient in Case 3, whose basal metabolic rate was raised and serum cholesterol normal, had an auricular flutter.

Parathyroid function-The similarity between the cataract occurring in dystrophia myotonica and that occurring in the tetany of hypoparathyroidism has been noted by many workers. Calcium metabolism has been studied in the former condition. Waring, Ravin and Walker 
(1940) reported normal serum-calcium and serum-phosphorus levels in all their patients, and Milhorat and Toscani (1939) reported a normal calcium and phosphorus balance in one patient whom they examined. The serum-calcium and serum-phosphorus levels were determined in most of the patients in the series, and in some cases the alkaline phosphatase was estimated (Table VII). The results were normal.

TABLE VII

\begin{tabular}{|cccc|}
\hline $\begin{array}{c}\text { Case } \\
\text { number }\end{array}$ & $\begin{array}{c}\text { Serum-calcium } \\
\text { (milligrams/100 millititres) }\end{array}$ & $\begin{array}{c}\text { Serum-phosphorus } \\
\text { (milligrams/100 millilitres) }\end{array}$ & $\begin{array}{c}\text { Plasma alkaline } \\
\text { phosphatase } \\
\text { (King-Armstrong units) } \\
\text { (normal, 4-13) }\end{array}$ \\
\hline 1 & $10 \cdot 7,10 \cdot 5,9 \cdot 1$ & $4 \cdot 0,3 \cdot 3$ & 17,22 \\
2 & 10.7 & 3.6 & 3.2 \\
3 & 10.4 & $3 \cdot 2$ & 6 \\
5 & 10.8 & - & - \\
6 & 10.8 & - & - \\
7 & 10.3 & 4.0 & 8.0 \\
8 & $10.7,9.9$ & $2.0,3.0$ & 6.9 \\
9 & 10.1 & $2 \cdot 2$ & 4.0 \\
\hline
\end{tabular}

Since serum-calcium levels as low as those occurring in tetany due to hypoparathyroidism have never been recorded in a patient with dystrophia myotonica, and since no abnormality in calcium or phosphorus metabolism has yet been demonstrated, it appears that decreased parathyroid function is not a factor in this disease.

\section{CHANGES IN THE SKULL IN DYSTROPHIA MYOTONICA}

Few authors have referred to the bone changes in the skull in dystrophia myotonica. Scharnke and Full (1920) reported large frontal sinuses in the presence of a normal pituitary fossa. Rouquès (1931) reported radiographic abnormalities in the skull in four patients. In three there was distinct thickening of the calvarium; large frontal sinuses occurred in two; in two the pituitary fossa was small, and in two the fossa was abridged by calcification. Fagin (1946) reported hyperostosis frontalis in two patients and Correia de Oliveira and Mosinger (1951) discussed hyperostosis frontalis interna associated with the disease.

In three papers, Caughey and Brown (1950) and Caughey $(1952 a, 1952 b)$ discussed the skull changes and stressed the frequency of this finding. Of fifteen cases with skull changes, ten were in males and five in females. Since 1952 several new cases have been observed. (Case records in Appendix 1.)

The radiological features observed (Fig. 4) have been a general thickening of the whole calvarium, hyperostosis frontalis and fronto-parietalis, a small pituitary fossa, a general increase in the air cells of the frontal and ethmoidal sinuses with pneumatisation of the dorsum sellae and, in some, prognathism. In some cases most of these features may be present, in others only one or two (Fig. 5). A résumé of the skull defects in twenty-two cases is seen in Table VIII.

These skull changes have been observed in the dystrophic generation in patients with the fully developed disorder. In this series no record has been found of skull changes presenting in those patients, usually of the first generation, who present with cataract alone, nor in those members of the third generation who present with congenital physical and mental defects, as described by Caughey and Barclay (1954). The incidence of the skull changes in this series 
of thirty-seven cases with the fully developed disorder, who have had a skull radiograph, was twenty-two ( 59.5 per cent). The sex incidence was thirteen men and nine women. The ages ranged from twenty-seven to fifty-one years.

The incidence of hypogonadism is difficult to assess, especially in the women. It will be observed in Table VIII that eight patients had hypogonadism. This diagnosis was made on the clinical testing and the examination of the testicles. In two, gonadal biopsy revealed atrophy of the seminiferous tubules and of the interstitial elements.

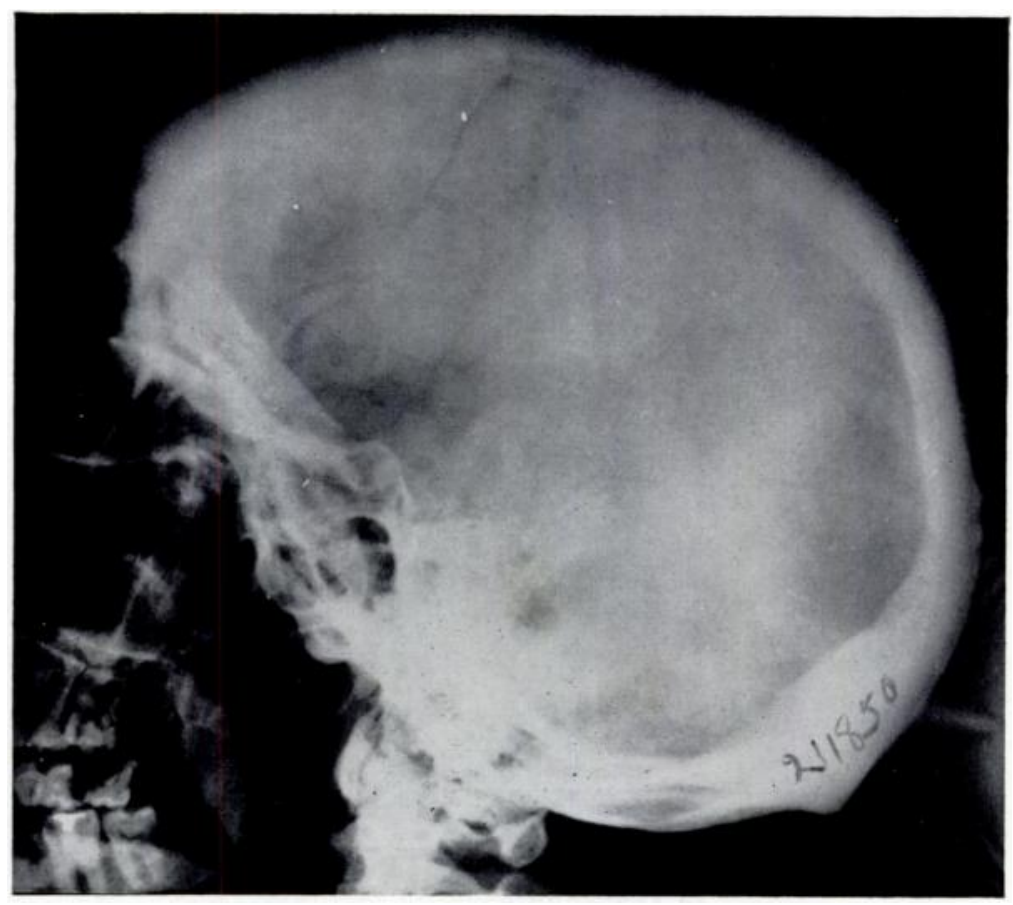

FIG. 4

Dystrophia myotonica with hyperostosis calvariae diffusa.

These changes in the skull may at best be described as acromegaloid changes. In one patient reported above, with well marked acromegaloid changes, there was a large pituitary gland and an enlarged pituitary fossa. These changes suggest some increased activity of growth hormone at some period in the natural history of this disease.

\section{DISCUSSION}

The occurrence of hyperostosis cranii in men and women alike who have dystrophia myotonica suggests that a study of dystrophia myotonica may yield a clue to our understanding of the syndrome of hyperostosis cranii.

In dystrophia myotonica the striking endocrine feature is the gonadal atrophy which is common to both sexes. The low levels of urinary 17 -ketosteroids that have been reported in the men suggest that there is a failure of the androgenic function of the gonads and of the adrenals. In the two women in the series, also, the same low levels support the suggestion of a failure of the androgenic function of the adrenals.

It is possible that, in consequence of the failure of androgenic function, the anterior pituitary gland responds by an increase of gonadotrophic activity and also of growth hormone in some cases. The hyperostosis cranii is a likely manifestation of the increased activity of growth hormone. 
Animal studies-In order to develop the argument it is necessary at this stage to discuss some aspects of the gonadal-pituitary function.

Castration of rats and mice leads to over-activity of gonadotrophic basophil cells which in time may go on to form pituitary adenomata. Griesbach and Purves (1956) reported basophil adenomata in seven out of eight rats castrated at nine months and examined twenty-seven months later. In rats castrated at birth Houssay, Houssay, Cardeza and Pinto

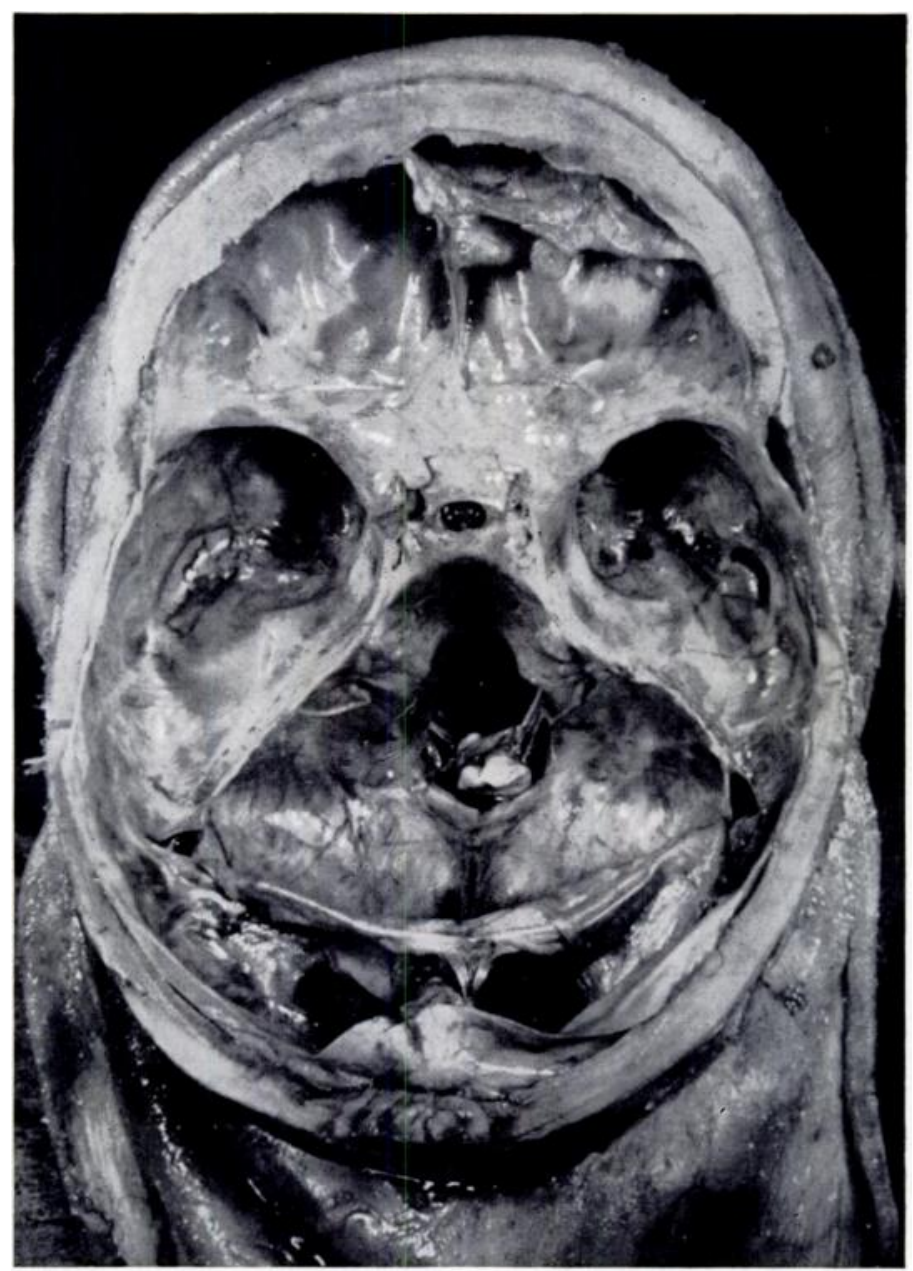

Fig. 5

Skull in case of dystrophia myotonica with hyperostosis frontalis and small pituitary fossa.

(1955) reported a high incidence of basophil adenomata in eighteen months to two years. Griesbach and Purves (1956) observed adenomata fifteen months after castration of rats six weeks old.

Effects of testicular secretions upon the pituitary function in man-The testes exert a regulating action upon the output of gonadotrophins by the pituitary gland during the early phases of adolescence when the quantities of urinary gonadotrophins are small (Hamilton 1948). In three boys with a follicular-stimulating hormone level of 3.5 mouse units before castration, the level of follicular-stimulating hormone rose to abnormally high levels of 5.0 mouse units or more after castration. Such high levels are not seen during normal adolescence (Catchpole 
TABLE VIII

Skull Defects in Dystrophia Myotonica

\begin{tabular}{|c|c|c|c|c|c|}
\hline $\begin{array}{c}\text { Case } \\
\text { number }\end{array}$ & Age & Sex & $\begin{array}{l}\text { Status of } \\
\text { dystrophia } \\
\text { myotonica }\end{array}$ & Hypogonadism & Calvarium \\
\hline 1 & 45 & $\mathbf{M}$ & Fully developed & Yes & Thickened \\
\hline 2 & 42 & $\mathbf{M}$ & Fully developed & Yes & Normal \\
\hline 3 & 26 & $\mathbf{M}$ & Fully developed & Reported normal & Thickened \\
\hline 4 & 33 & $\mathbf{F}$ & Fully developed & Three children & Thickened \\
\hline- & 27 & $\mathbf{M}$ & Fully developed & No & Thickened \\
\hline 5 & 32 & $\mathbf{M}$ & Fully developed & No & Normal \\
\hline 6 & 41 & $\mathbf{M}$ & Fully developed & Yes ++ & Normal \\
\hline 7 & 51 & $\mathbf{F}$ & Fully developed & Yes & Thickened \\
\hline 8 & 28 & $\mathbf{M}$ & Fully developed & Yes & Thickened \\
\hline 9 & 33 & $\mathbf{M}$ & Fully developed & Yes & Small, thickened \\
\hline 10 & 45 & $F$ (single) & Fully developed & $?$ & Thickened \\
\hline 11 & 47 & $\mathrm{~F}$ & Fully developed & $?$ & Thickened \\
\hline 12 & 42 & $F$ (single) & Fully developed & - & Marked thickening \\
\hline- & 42 & $\mathbf{M}$ & Fully developed & Yes & Marked thickening \\
\hline 13 & 43 & $\mathbf{M}$ & Fully developed & Yes & Thickened \\
\hline 14 & 35 & $\mathrm{~F}$ & Fully developed & No & Thickened \\
\hline 15 & - & $\mathbf{F}$ & Fully developed & No & Thickened \\
\hline 16 & 44 & $\mathbf{M}$ & Fully developed & $?$ & Thickened \\
\hline 17 & 40 & $\mathbf{M}$ & Fully developed & $?$ & Thickened \\
\hline 18 & 49 & F & Fully developed & $?$ & Thickened in frontal \\
\hline 19 & 43 & $F$ (single) & Fully developed & $?$ & Thickened somewhat \\
\hline 20 & 28 & $\mathbf{M}$ & Fully developed & - & Thickened \\
\hline
\end{tabular}

1942), and it suggests that in early adolescence the testicular function restrains the production of gonadotrophins by the pituitary gland. Catchpole, Hamilton and Hubert (1942) found in a study of eunuchs that the average urinary excretions of gonadotrophins was 40 or more mouse units. This is larger than that excreted by normal young men (Werner 1943). Hamilton, Catchpole and Hawke (1945) showed that the high level of urinary gonadotrophins may persist for as long as fifty years after castration. It is the usual finding in men who have been castrated early in life and live to an old age. Thus there is evidence of an overactivity of basophil gonadotrophic cells of the anterior lobe in man, like that which occurs in rats and mice.

Acromegaloid features in hypogonadism have been reported by Koch (1921), Wagenseil (1927) and McCullagh and Renshaw (1934). Hamilton, Catchpole and Hawke (1945) found two examples in a series of 200 eunuchs. No case is described in the literature in which gross acromegaly has developed. There does, however, seem to be adequate evidence to 
TABLE VIII-continued

\begin{tabular}{cccc}
\hline $\begin{array}{c}\text { Hyperostosis } \\
\text { frontalis interna or } \\
\text { fronto-parietalis }\end{array}$ & Pituitary fossa & Sinuses & Prognathism \\
\hline H.F.P. & Small & Dorsum sellae pneumatised & No \\
No & Small & Frontals +++ & No \\
H.F.I. & Very small & Frontal deep & - \\
H.F.P. & Small & Dorsum sellae pneumatised & No \\
H.F.I. & Small & Normal & No \\
No & Small & Large & - \\
No & Small & Frontal deep and extensive & Yes \\
Extensive H.F.P. & Very small, calcified on floor & Normal & No \\
Extensive H.F.P. & Very small & Dorsum sellae pneumatised. & No \\
No & Others extensive and deep & Yes \\
Marked H.F.P. & Small & Extensive, deep. & Dorsum sellae pneumatised \\
H.F.I. & Small & Sphenoidals large & Yes \\
H.F.I. & Small & Normal & No \\
H.F.I. & Small and bridged over & - & - \\
Marked H.F.I. & Enlarged & - & No \\
H.F.I. early & Small & Extensive frontal & Yes \\
H.F.I. & Normal & Normal & No \\
H.F.I. & Small & Normal & - \\
H.F.I. & Normal & Normal & No \\
H.F.I. & Small & Normal & No \\
H.F.I. & Small & Normal & No \\
H.F.I. & Small & Normal & No \\
\hline & & Dorsum sellae pneumatised & - \\
\hline & & & \\
\hline
\end{tabular}

suggest that when the restraining action of the testes is removed, the pituitary may excrete an excess of growth hormone.

In an attempt to correlate hypogonadism with the development of pituitary tumours in man, a search was made of some of Cushing's (1912) classical case records and records of fifty other cases of pituitary tumour (Caughey 1957). Cushing mentioned a married woman with a pituitary tumour in whom there was evidence of gonadal defect. At operation both ovaries were cystic and small. He also reported the case of a single woman of twenty-six with a pituitary tumour who had had a period at fourteen years and thereafter amenorrhoea. At a gynaecological operation she was found to have bilateral cystic fibrous ovaries.

Two of the personal cases reported (Caughey 1957) were in women who had had bilateral oophorectomy over twenty years before and subsequently developed pituitary tumours. Two men with hypogonadism of long standing developed pituitary tumours, and one patient with 
dystrophia myotonica, gonadal atrophy, hyperostosis cranii and acromegaloid changes had an enlarged pituitary fossa and an enlarged pituitary gland.

From these facts it seems evident that after the development of hypogonadism in males and in females, the pituitary gland usually responds by an increase in the gonadotrophic activity, both in animals and in man. Less often in man there may be an increase in the output of growth hormone leading to acromegaloid features.

Effects of growth hormone on the skull-It is well recognised that generalised overgrowth in the human may eventually be associated with disproportion of skeletal parts and localised bony overgrowths which are the most characteristic features of acromegaly. Similar changes have been reproduced in different animals: in the dog by Putnam, Benedict and Teel (1929) and by Evans, Simpson, Meyer and Reichert (1933), and in the guinea pig and mice by Silberberg and Silberberg (1943). Asling, Simpson, Moon, Li and Evans (1955) reported the details of some of these changes in rats. In the skull there were certain characteristic changes like those observed in acromegaly. There was increased length and breadth of skull of the injected rats with an increase in the height of the ridges at muscular attachments, and general thickening of bone. Section through the bone showed clearly increased thickness of the laminae. The haemopoietic marrow was expanded within the diplöe.

Hyperostosis cranii in dystrophia myotonica-It is suggested that, in consequence of the failure of androgenic function of the gonads and of the adrenal glands, the usual restraining influence on the anterior pituitary gland is removed, one result of which is the high levels of follicular-stimulating hormone. Also in some of these cases there is a release of growth hormone which accounts for the excessive sinus formation-prognathism and the hyperostosis cranii. The smallness of the pituitary fossa can be explained by involvement in the hyperostosis.

The marked tendency to hyperostosis cranii in acromegaly lends support to the suggestion that excessive growth hormone accounts for the hyperostosis. In women with the Morgagni syndrome, with hirsutism and hyperostosis cranii, the virilism could be brought about by the overactivity of the adrenal cortex. Excessive androgens in turn suppress normal oestrogenic function of the gonads and the adrenals. Consequently, restraint is removed from the pituitary growth function and hyperostosis cranii develops.

Hence in these three conditions in which hyperostosis often occurs, a common factor is the releasing of the usual restraint from the growth hormone, which in turn could account for the hyperostosis cranii common to the three.

\section{SUMMARY}

1. The clinical features of hyperostosis cranii are briefly reviewed. In large series of cases the syndrome has been found to occur almost entirely in females.

2. In recent studies of dystrophia myotonica, it is apparent that hyperostosis cranii is one of the variable features of the disorder. This disease occurs equally among males and females and the hyperostosis cranii also is distributed equally among males and females.

3. Hyperostosis cranii also occurs in patients with Morgagni's syndrome, with acromegaly, and as " senile hyperostosis."

4. The etiology of hyperostosis is still a matter for speculation. More recent studies have focused attention on the endocrine system, and it seems probable, in view of the sex distribution in dystrophia myotonica, that the key to the problem may be found in this disorder.

5. In dystrophia myotonica the characteristic skull changes are hyperostosis cranii, a small pituitary fossa, excessive sinus formation and prognathism. These are acromegaloid changes. Gonadal atrophy is a common feature and endocrine study suggests that the endocrine defect is primarily a failure of the androgenic function of the adrenals and the testes. 
6. In rodents and in humans ablation of the gonads leads to overactivity of gonadotrophic cells and, at times, of somatotrophic cells. Sometimes pituitary tumours develop.

7. Acromegaloid features may occur in eunuchs, and it is likely that the acromegaloid changes in dystrophia myotonica are of the same order from overactivity of growth hormone.

8. In animals excess of growth hormone produces thickening of the skull.

9. In dystrophia myotonica, acromegaly, and Morgagni's syndrome, it is suggested that hyperostosis cranii is an expression of unrestrained activity of growth hormone.

\section{APPENDIX 1}

FAMILY I

CASE REPORTS

Case 1-Myopathy, myotonia, bilateral cataract, premature frontal baldness, hypogonadism, hypothyroidism, small pituitary fossa and hyperostosis frontalis.

The patient was an unmarried man of forty-five, pensioned owing to disablement. At the age of about twenty-seven he had noticed wasting of the arms, legs and neck muscles. This had progressed steadily and for the last three years he had been completely disabled, being unable to raise his head or to stand alone. Five years after the onset of muscle wasting he found difficulty in relaxing his grasp, and about the same time his vision began to fail because of bilateral lenticular opacities. Cataracts were successfully treated five years later. Seven years after the onset he had to give up farming on account of increasing weakness. Frontal baldness had developed in his early twenties. He first shaved at the age of seventeen years, and since then had not had to shave more than every third day. The hair on his body had become soft and scanty during the past ten years. Sexual power and libido had deteriorated, but he still had some potency and occasional nocturnal emissions. He had complained of the cold in recent years. His parents and grandparents were healthy. One brother, aged forty-one, had bilateral lenticular opacities but no other evidence of the disease. Another brother and a sister were normal. An aunt on the maternal side had cataracts, but was not examined.

On examination the patient's measurements were: height, 5 feet 10 inches; span, 5 feet 10 inches; vertex to symphysis pubis, 2 feet 11 inches; symphysis pubis to sole, 2 feet 11 inches. The facial hair was soft and scanty on the chin and moustache area. The pubic hair was of female distribution, the axillary hair was normal, and there was no hair on the legs. The skin of his fingers was shiny and dystrophic in appearance. He was unable to sit without assistance, and required help when walking. Visual acuity was reduced, as a cataract had been removed from each eye. The facial muscles were wasted and very weak, and there was almost complete atrophy of both sternomastoid muscles. There was great wasting and weakness of all the muscles of the forearms. The abdominal muscles were weak, and the lower limbs were wasted and weak in all movements. The gait when assisted was unsteady and of a "slapping" and " steppage" type. When he was seen about twelve years before, there had been myotonia of the grasp, but, probably because of excessive weakness, this was now slight. There was slight mechanical myotonia in the tongue and the thenar and hypothenar eminences. All the deep reflexes were lost. Sensory appreciation was normal. The testes were soft and very small. His mental state was good. He was co-operative and not subject to any variations in mood. The cardiovascular system was normal, with a blood pressure of $150 / 75$. Other systems were normal.

Investigations-The blood count was normal and the Kahn reaction negative. The cerebrospinal fluid was normal. The basal metabolic rate was -48 per cent and -34 per cent. The serum-cholesterol was 360 milligrams per 100 millilitres, the total non-protein nitrogen 33 milligrams per 100 millilitres, the serum-chlorides 556 milligrams per 100 millilitres (as $\mathrm{NaCl})$, the serum-calcium 10.7, 10.5 and 9.1 milligrams per 100 millilitres, serum-sodium 327 milligrams, and serum-potassium 17 milligrams per 100 millilitres. The serum acid phosphatase was 1.2 units, and alkaline phosphatase 22 KingArmstrong units. Tests of glucose tolerance and insulin tolerance in 1947 and 1949 showed a delayed return of the blood sugar to a normal level after 50 grammes of glucose, and a delayed fall in the blood sugar level after insulin (Tables III and IV). The excretion of follicle-stimulating hormone was positive to 96 mouse units. The potassium resistance test for adrenal cortical function (Cutler, Power and Wilder 1938) gave an equivocal result. The 17-ketosteroid excretion was 1.3 and 1 milligram per 100 millilitres in twenty-four hours. The electrocardiograph showed elevation of the ST segment in leads I and II, and slight ventricular myocardial damage seemed probable (Dr E. Roche). Radiologically the lung fields were clear and the heart shadow normal. A radiograph of the skull showed the vault to be normal in shape, and the calvarium thickened, with hyperostosis interna frontalis et parietalis; the sinuses were within normal limits, the mandible was normal and the sella turcica small, with a pneurnatised dorsum sellae. The pineal body was calcified.

VOL. 40 B, NO. 4, NOVEMBER 1958 


\section{FAMILY II}

Members of two families with the same father were investigated. The father was examined and had a bilateral posterior polar cataract but no other signs of dystrophia myotonica. By his first wife he had a son (Case 2), and a daughter who was not examined. By his second wife he had three sons and a daughter, all of whom had the complete picture of the disorder. Two of them (Cases 3 and 4) are described.

Case 2-Myopathy, myotonia, bilateral cataract, frontal baldness, hypoganadism and a small pituitary fossa.

This patient was a retired farmer aged forty-two. In 1941 he had become aware of difficulty in relaxing his grasp, soon followed by weakness and wasting of the forearm, leg and neck muscles. The wasting and weakness had progressed and the myotonia had persisted. For four years there had been impairment of sexual power and libido, with complete loss of potency in the last six months. Frontal baldness began in his early twenties. He had lately become irritable and less reliable.

On examination, he had extensive body hair and normal facial hair. There was general wasting of the facial, temporal and sternomastoid muscles, the latter giving a rounded swan-like appearance to the neck. The deltoid muscles were hypertrophied but weak, and there was severe wasting and weakness of the forearms and upper arms, the small muscles of the hands being unaffected. There was great wasting of the legs, and to a lesser extent of the thighs. All the deep reflexes were much impaired. The grasp was myotonic on both sides, and myotonia of the tongue, thenar, hypothenar and calf muscles was present on percussion. Visual acuity was reduced to $6 / 12$ in both eyes by lenticular opacities. The testes were small and soft. The cardiovascular system was normal.

Investigations - The blood Kahn test was negative and a blood count was normal. The serum-calcium was 10.7 milligrams, serum-phosphorus 3.6 milligrams, and serum-cholesterol 180 milligrams per 100 millilitres. The cerebrospinal fluid was normal, the basal metabolic rate was -12 per cent and -8 per cent. The electrocardiograph was normal. The glucose tolerance and insulin tolerance tests gave normal results (Tables III and IV). The excretion of 17-ketosteroid on two estimations was 2.5 and 4.5 milligrams in twenty-four hours. A radiograph of the chest was normal. The skull showed a normal vault, large frontal sinuses and a normal sella turcica. The mandible and the pineal body were not seen.

Case 3-Myotonia, myopathy, auricular flutter.

An unmarried man aged twenty-six, a panel beater, developed palpitation and breathlessness and was admitted to hospital (1945), where auricular flutter was diagnosed. For two years he had noticed difficulty in relaxing his grasp, and weakness of his wrists and legs. Frontal baldness began to develop at the age of twenty-one. The sexual functions were unimpaired.

On examination, he was slightly built. The body hair and pubic hair were normal. The facies was myopathic, and the neck rounded and swan-like from wasting of the sternomastoid muscles. The forearms were wasted, and the extensors of the wrists weak. The deep reflexes of the arms were absent; the knee jerks were reduced. There was myotonia of the grasp and myotonia on percussion of the tongue, thenar and hypothenar eminences, and calves. The testes were normal. The visual acuity was normal, and there were no lenticular opacities. The pulse rate was 110 per minute, the rhythm was regular, and the vessels were soft. The apex beat was in the fifth space, three inches from the mid-line. The heart sounds were normal, and there were no murmurs. The blood pressure was $115 / 85$. An electrocardiograph showed an irregular rhythm with a 4:1 to 7:1 flutter. The ST segment was normal. Investigations-The blood count was normal, and the Kahn reaction negative. The serum-calcium was 10.4 milligrams, serum-phosphorus 3.2 milligrams, and serum-cholesterol 210 milligrams per 100 millilitres. The basal metabolic rate was +38 per cent and +27 per cent. The serum acid phosphatase was 2 units. Glucose tolerance (Table III) and insulin tolerance were normal. The excretion of 17 -ketosteroid on two estimations was 4.2 milligrams and 5.5 milligrams in twenty-four hours. A radiograph of the chest was normal. The skull showed a vault of normal shape; the bones were thickened, especially in the posterior parietal region. There was parietal hyperostosis interna extending to the frontal region. The frontal sinuses were deep and the sella turcica was normal. The mandible and the pineal body were not seen.

Case 4-Myotonia, muscular dystrophy, bilateral cataract.

A married woman, aged thirty-three, had noticed a difficulty in relaxing her grasp for twelve years, and six or seven years later a weakness and wasting of her right leg. Soon afterwards the weakness and wasting had become apparent in the left leg, upper limbs, neck and face. Next she found difficulty in holding her back straight, and, at times, a tendency to overbalance. For three years she had noticed deterioration of her vision, and eighteen months ago the vision in her right eye had failed completely, and a cataract was excised. The left eye subsequently failed and a cataract was removed. She had had 
three children. The first had a cleft palate, and died of meningitis. . The second had a cleft palate and hare lip, and the third child was alive and well.

Examination showed a myopathic facies, with wasting of all the facial muscles; the neck was swan-like from complete wasting of the sternomastoids. There was wasting of the forearms, with weakness which was more marked in the dorsiflexors of the wrists. The muscles of the legs were wasted, and the dorsiflexors of the feet weak. The grip was myotonic and there was myotonia on percussion of the tongue, thenar and hypothenar eminences. All the deep reflexes of the lower limbs were absent. Before her operation for cataract there were bilateral lenticular opacities; on slit-lamp examination these were punctate or small and scale-like, some of those situated under the cortex being bluish-green. Outside the nucleus they had gradually increased so that both lenses were opaque (Mr W. A. Fairclough). A radiograph of the skull showed a normal-shaped vault; the calvarium was thickened throughout, with marked hyperostosis frontalis interna and hyperostosis parietalis, somewhat resembling that seen in Paget's disease. The sinuses were within normal limits, with pneumatisation of the dorsum sellae. The sella turcica was within normal limits. The pineal body was calcified. Laboratory investigations were incomplete. The 17-ketosteroid excretion was 2.3 milligrams in twenty-four hours.

\section{FAMIIY III}

Case 5-Myotonia, myopathy, cataract, frontal baldness.

A returned soldier aged thirty-two had noticed difficulty in relaxing his grip while a prisoner of war in 1944, and this was soon followed by wasting and weakness of the right shoulder muscles. The wasting went on to involve the muscles of the face, neck, forearms, shoulder girdles and legs. His vision had recently deteriorated. There had been no impairment of sexual power or libido.

Examination showed extensive frontal baldness and a myopathic facies, with early wasting of the facial muscles. The sternomastoid muscles were completely wasted, and there was great wasting of the left deltoid and pectoral muscles, and of the spinati and trapezii. The lower limbs were normal. There was myotonia of the grip and myotonia on percussion of the tongue, the thenar and hypothenar eminences, the deltoids and the flexors of the forearms. The knee jerks were diminished and the right ankle jerk was absent. Visual acuity was unimpaired but both eyes showed early cataract, with a few striae radiating from the posterior pole of the right lens and a few minute opacities in the left lens. The slit-lamp examination revealed multiple punctate opacities of various sizes in the anterior cortex of both lenses, more marked at the equator. A few of the opacities were greenish in colour.

Investigations-A blood count was normal, and the blood Wassermann reaction negative. The cerebrospinal fluid was normal. The serum-calcium was 10.8 milligrams per 100 millilitres, and serum-cholesterol 180 milligrams per 100 millilitres; 17 -ketosteroid excretion was 4.8 milligrams in twenty-four hours. Insulin sensitivity was normal (Table IV). Biopsy from the left deltoid muscle showed irregular changes in the muscle fibres, some of which were hypertrophic and many wasted, and an increase of fibrous tissue. There was loss of the transverse striations and multiplication of the nuclei.

\section{FAMILY IV}

Case 6-Complete picture of dystrophia myotonica: myotonia, wasting, cataracts, failure of sexual power and libido, left bundle branch block.

A carpenter aged forty-one had noticed failure of sexual power for seven years, and this went on to complete loss of potency and libido. Four years later his grasp became difficult to relax, there was weakness of the arms and legs, and difficulty in swallowing, and his speech became slurred.

On examination he was bald, with a myopathic facies. His speech was somewhat slurred and thick. The sternomastoid muscles were completely wasted. There was great wasting and weakness of all four limbs and of the abdominal muscles. Voluntary myotonia affected the grasp of both hands, and there was myotonia on percussion. All the deep reflexes were absent. The pubic hair was scanty. The testes were small and soft, and the prostate gland was small. Visual acuity was normal. Slit-lamp examination revealed multiple punctate subcapsular opacities, longer and more numerous at the periphery. A few were green. There were posterior cortical radial opacities in both lenses. The pulse was slow and regular. The heart was not enlarged, and there was reduplication of the second sound at the apex. The blood pressure was 100/55.

Investigations-A blood count was normal, and a blood Kahn test was negative. The cerebrospinal fluid was normal. The 17-ketosteroid excretion was 1.7 milligrams in twenty-four hours. A gastric test meal showed a low total acidity. Electro-cardiography showed the heart rate to be 50 per minute: the P waves were of low voltage, the PR interval 0.26 seconds, the QRS complexes widened, and the ST segment depressed in leads I and II and elevated in lead $V_{4} ; T$ was biphasic in leads I and II, and high in lead $\mathrm{V}_{\mathbf{4}}$. These findings suggested an impaired function of the sino-auricular node and 
myocardial damage affecting bundle conduction, with a block of the left bundle branch. An electrocardiograph taken two weeks later revealed no change. A radiograph of the chest was normal. The skull showed a normal vault with well marked venous lacunae; the frontal and sphenoid sinuses were extensive and deep, the latter extending into the posterior clinoid processes. The mandible was elongated. The sella turcica was possibly small, but showed no calcification within; the dorsum sellae was completely pneumatised. The pineal body was not seen.

\section{FAMILY V}

Case 7-Myopathy, myotonia, bilateral cataract, small pituitary fossa and hyperostosis frontalis.

A married woman aged fifty-one had noticed weakness of her neck muscles since the age of thirty. In the past five years there had been progressive wasting and weakness of the forearms and legs, so that she had been bedridden for a year. At times she had noticed some difficulty in relaxing her grasp, but this was not troublesome. Her vision had not failed noticeably, but there had been loss of libido for several years. She had two sons, the younger-aged twenty-eight years-having the fully developed disease (Case 8). The elder son was well. There was no history of cataract in the family.

On examination she had grey hair, no baldness, and a myopathic facies. Her speech was slurred. The body hair and eyebrows were somewhat scanty, but of normal female distribution. The skin was soft and of fine texture. There was some wasting of the facial muscles. The sternomastoid muscles were almost completely atrophied and were powerless. There was great weakness and wasting of the forearms and legs. Myotonia was slight. All the deep reflexes were reduced, and the ankle jerks absent. There were bilateral posterior polar cataracts. The mental state was normal, and she was of average intelligence. The cardiovascular system was normal.

Investigations-The serum-calcium was 10.3 milligrams and serum-phosphorus 4 milligrams per 100 millilitres. The serum-sodium was 335 milligrams, serum-chlorides 556 milligrams (as $\mathrm{NaCl}$ ), and serum cholesterol 310 milligrams per 100 millilitres. A glucose-tolerance test showed a delay in the return of the blood sugar to a normal level. Insulin sensitivity was normal (Tables III and IV). The excretion of follicle-stimulating hormone was strongly positive to 96 mouse units. The 17-ketosteroid excretion was 1.8 milligrams in twenty-four hours. The water excretion test for adrenal cortical function (Robinson, Power and Kepler 1941) was suggestive of impaired function. The volume of the night urine was $\mathbf{4 3 5}$ millilitres, and that of the largest day specimen 315 millilitres, giving an index of 38. The basal metabolic rate was -4 per cent. An electrocardiograph showed low voltages throughout, a left bundle branch block, and probably a first degree of heart block. A radiograph of the chest was normal. The skull showed the vault to be normal in shape, but possibly enlarged from thickening of all the membranous bones; there was extensive hyperostosis frontalis interna. The thickening was somewhat patchy, resembling that seen in Paget's disease. The sinuses and mandible were normal. The sella turcica was small, with calcification near the floor; there was no pneumatisation of the dorsum sellae. The pineal body was not seen.

Case 8-Myopathy, myotonia, cataract, hypogonadism, mental retardation, small pituitary fossa, and hyperostosis frontalis.

This patient, a pensioner aged twenty-eight, was the younger son of the previous patient (Case 7). At school he was backward but did not require special schooling. On leaving school at the age of thirteen he was unable to take up any regular employment. At seventeen he noticed difficulty in relaxing his grasp, soon followed by weakness and clumsiness of his arms, legs and neck muscles. The weakness and wasting progressed slowly. For two years before examination his vision had been deteriorating.

On examination he was a dark, swarthy man of inferior intelligence. His facies was myopathic, with a slow lingering smile. There was early recession of the hair in the frontal region, but the body hair was normal and of male distribution. His speech was slurred and indistinct. There was wasting of the sternomastoid muscles and of the muscles of the forearms and legs. There was marked myotonia of the grasp and, on percussion, of the tongue and small muscles of the hands. The knee and ankle jerks were absent. There was bilateral polar cataract. The testes were small and soft, but had normal sensation. The scrotum and penis were of normal size. The body dimensions were: height, 5 feet $5 \frac{1}{2}$ inches; span, 5 feet $5 \frac{1}{2}$ inches; vertex to pubis, 2 feet 9 inches; pubis to soles, 2 feet $8 \frac{1}{2}$ inches.

Investigations-The serum-sodium was 332 milligrams, and serum-potassium $17 \cdot 5$ milligrams per 100 millilitres; the serum-cholesterol 200 milligrams, serum-calcium 9.9 milligrams and the serumphosphorus 2.0 milligrams per 100 millilitres. Glucose tolerance and insulin sensitivity (Tables III and IV), and the clinical response of the patient to insulin, were normal. The 17-ketosteroid excretion was 1.2 milligrams in twenty-four hours. The water excretion test (Robinson, Power and Kepler 1941) produced 300 millilitres of night urine, and the greatest hourly volume of day urine after fluid was 210 millilitres, giving an index of 35 . The excretion of follicle-stimulating hormone was positive to 
96 mouse units. An electrocardiograph showed a PR interval of $0 \cdot 17$ seconds, and a very small $R$ wave in leads $V_{2}$ and $V_{3}$, with the probability of myocardial damage (Dr E. G. Sayers). A skull radiograph showed the vault to be normal in size; all the membranous bones were thickened, with extensive hyperostosis frontalis interna and hyperostosis parientalis interna. The sclerosis was patchy, to some extent resembling that of Paget's disease. The sinuses were extensive and deep. The sella turcica was small, and the dorsum sellae thick and partly pneumatised. The pineal body was possibly calcified. The intelligence quotient by Wechsler's performance test was 74 .

\section{FAMILY VI}

Case 9-Myopathy, myotonia, hypogonadism, mental retardation, and a small pituitary fossa.

A grocer aged thirty-three had always been a frail individual and afraid of other boys. At school he had been backward. His occupational history was unsatisfactory and for the last year he had been unemployed. He had first noticed difficulty in relaxing his grasp when aged thirteen. At the age of fifteen he had noticed that his arm and leg muscles were becoming weaker and were wasting. The difficulty with his grip had become increasingly great. He had begun shaving at the age of twenty-one, and at thirty-three shaved every third day. His vision had not deteriorated. He felt the cold very much. Neither of his parents, to his knowledge, had any wasting, muscle disability or cataract. A paternal cousin had wasting of his arms and legs. A brother and sister of the patient were reported to be well.

On examination he was thin, with a disinterested look, and below the average in intelligence. The head hair was dark, fine and scanty, and the eyebrows were scanty. The facial hair was scanty and confined to the moustache and chin areas. The axillary and pubic hair were also scanty, the latter being of female distribution. The hair on the legs was fine but of normal distribution. The skin was dry and atrophic, with numerous melanomata. The thyroid gland was not palpable. There was marked myotonia of the grip, and myotonia of the tongue and thenar eminences on percussion. The facies was myopathic, and there was wasting of the sternomastoids and, to a lesser degree, of the limb muscles. The deep reflexes were normal. No cataract was present. The prostate gland was small. The cardiovascular system was normal.

Investigations-The blood Kahn test was negative. The serum-sodium was 340 milligrams, serumpotassium 16 milligrams, and serum-chloride 580 milligrams per 100 millilitres; the serum-cholesterol was 280 milligrams and the serum-calcium $10 \cdot 1$ milligrams per 100 millilitres. Glucose tolerance and insulin sensitivity (Tables III and IV), and the clinical reaction to insulin, were normal. The 17ketosteroid excretion was 3.1 milligrams in twenty-four hours. The water excretion test (Robinson, Power and Kepler 1941) produced 360 millilitres of night urine, and the greatest hourly day urine after fluid was $\mathbf{2 7 0}$ millilitres, giving an index of 31. Excretion of follicle-stimulating hormone was positive to 96 mouse units. An electrocardiograph showed some slurring of $\mathbf{R}$ in leads I and II, probably representative of myocardial damage. A radiograph of the skull showed a small, globoid and microcephalic vault. The bones were thick but of normal density, with marked venous lacunae. The sinuses were extensive and deep, especially the sphenoids, which extended into the posterior clinoid processes. The mandible was elongated. The sella turcica was very small, but showed no calcification within. The dorsum sellae was pneumatised. The pineal body was not seen.

I wish to thank the Director of the Armed Forces Institute of Pathology, Washington, D.C., for the original of Figure 5.

\section{REFERENCES}

Adie, W. J., and Greenfield, J. G. (1923): Dystrophia Myotonica (Myotonia Atrophica). Brain, 46, 73. Asling, C. W., Simpson, M. E., Moon, H. D., LI, C. H., and Evans, H. M. (1955): The Hypophyseal Growth Hormone, Nature and Actions (Ed. Smith, R. W., Gaebler, O. H., and Long, C. N. H.). Proceedings of an International Symposium on Growth Hormone 1954, p. 154. New York: McGraw-Hill Book Co. Inc.

BeNDA, C. E., and BixBY, E. M. (1947): Urinary Excretion of 17-Ketosteroids in Various Conditions of Oligophrenia Correlated with Some Autopsy Observations. Journal of Clinical Endocrinology, 7, 503.

Bonnamour, S., and Jamin (1926): Maladie osseuse de Paget au niveau du crane avec lipomatose énorme des membres inférieurs chez une femme ayant une tuberculose di poumon droit terminale. Lyon Médical, $128,535$.

Calame, A. (1951): Le Syndrome de Morgagni-Morel. Paris: Masson et Cie.

CARR, A. D. (1936): Neuropsychiatric Syndromes Associated with Hyperostosis Frontalis Interna. Preliminary Report. Archives of Neurology and Psychiatry, 35, 982.

Catchpole, H. R., Hamilton, J. B., and Hubert, G. R. (1942): Effect of Male Hormone Therapy on Urinary Gonadotropins in Man. Journal of Clinical Endocrinology, 2, 181.

Caughey, J. E. (1952a): Bone Changes in the Skull in Dystrophia Myotonica. Journal of Bone and Joint Surgery, 34-B, 343.

VOL. $40 \mathrm{~B}$, NO. 4 , NOVEMBER 1958 
Caughey, J. E. (1952b): Radiological Changes in the Skull in Dystrophia Myotonica. British Medical Journal, i, 137.

CAughey, J. E. (1957): The Aetiology of Pituitary Tumours: The Role of Hypogonadism and Hypothyroidism. Australasian Annals of Medicine, 6, 93.

Caughey, J. E., and Brown, J. (1950): Dystrophia Myotonica: An Endocrine Study. Quarterly Journal of Medicine, N.S. 19, 303.

Caughey, J. E., and Barclay, J. (1954): Dystrophia Myotonica and the Occurrence of Congenital Physical Defect in Affected Families. Australasian Annals of Medicine, 3, 165.

Caughey, J. E., GWYNNe, J. F., and JefFerson, N. R. (1957): Dystrophia Myotonica Associated with Familial Paget's Disease (Osteitis Deformans) with Sarcomata. Journal of Bone and Joint Surgery, 39-B, 316.

Correia de Oliveira and Mosinger, M. (1951): Dystrophie de Steinert-Batten associce à une hyperostose frontale interne de Morgagni-Stewart-Morel. IVe Congrès Neurologique International, Paris, 1949. Paris: Masson et Cie, 2, 115; 3, 409.

Cushing, H. (1912): The Pituitary Body and Its Disorders. Philadelphia and London: J. B. Lippincott Company. Cutler, H. H., Power, M. H., and Wilder, R. M. (1938): Concentrations of Chloride, Sodium and Potassium in Urine and Blood. Journal of the American Medical Association, 111, 117.

Dressler, L. (1927): Uber die Hyperostosen des Stirnbeins. Beiträge zur pathologischen Anatomie und zur allgemeinen Pathologie, 78, 332.

Evans, H. M., Simpson, M. E., MeYer, K., and Reichert, F. L. (1933): Growth and Gonad-Stimulating Hormones of the Anterior Hypophysis. Memoirs of the University of California, 11, 421.

FAGIN, I. D. (1946): Dystrophia Myotonica. Report of Two Cases, with Associated Hyperostosis Frontalis Interna in One. Journal of the Michigan State Medical Society, 45, 500.

Falconer, M. A., and Pierard, B. E. (1950): Failing Vision Caused by a Bony Spike Compressing the Optic Nerve Within the Optic Canal. Report of Two Cases Associated with Morgagni's Syndrome Benefited by Operation. British Journal of Ophthalmology, 34, 265.

FouIN, O. (1922): A System of Blood Analysis. Supplement III. A New Colorimetric Method for the Determination of the Amino-Acid Nitrogen in Blood. Journal of Biological Chemistry, 51, 377.

Fraser, R., Albright, F., and Smith, P. H. (1941): The Value of the Glucose Tolerance Test, the Insulin Tolerance Test, and the Glucose Insulin Tolerance Test in the Diagnosis of Endocrinologic Disorders of Glucose Metabolism. Journal of Clinical Endocrinology, 1, 297.

Fraser, R. W., Forbes, A. P., Albright, F., Sulkowitch, H., and Reifenstein, E. C., Jun. (1941): Colorimetric Assay of 17-Ketosteroids in Urine: A Survey of the Use of this Test in Endocrine Investigation, Diagnosis, and Therapy. Journal of Clinical Endocrinology, 1, 234.

GreIG, D. M. (1928): On Intracranial Osteophytes. Edinburgh Medical Journal, 35, 165.

Greulich, W. W., Dorfman, R. I., Catchpole, H. R., Solomon, C. I., and Culotta, C. S. (1942): Somatic and Endocrine Studies of Puberal and Adolescent Boys. Monographs of the Society for Research in Child Development, 7, no. 3.

Griesbach, W. E., and Purves, H. D. (1956): Basophil Cell Adenomas in the Rat Pituitary. Proceedings of the University of Otago Medical School, 34, 1.

Hamilton, J. B. (1948): The Role of Testicular Secretions as Indicated by the Effects of Castration in Man and by Studies of Pathological Conditions and the Short Lifespan Associated with Maleness. Proceedings of the Laurentian Hormone Conference, Recent Progress in Hormone Research, 3, 257.

Hamilton, J. B., Catchpole, H. R., and Hawke, C. C. (1945): Titers of Gonadotrophins in Urine of Aged Eunuchs. Journal of Clinical Endocrinology, 5, 203.

Henschen, F. (1936): Le " syndrome de Morgagni " (hyperostose frontale interne, virilisme, adipose). Annales d'anatomie pathologique et d'anatomie normale médico-chirurgicale, 13, 943.

Henschen, F. (1949): Morgagni’s Syndrome. Edinburgh: Oliver \& Boyd.

Houssay, B. A., Houssay, A. B., Cardeza, A. F., and Pinto, R. M. (1955): Tumeurs surrénales oestrogéniques et tumeurs hypophysaires chez les animaux castrés. Schweizerische Medizinische Wochenschrift, 85, 291.

JUNET, R. M. (1938): Histopathologie du squelette acromégalique et ses modifications sous l'influence de l'hyperthyroïdisme. Genève: Imprimerie Atar.

Klinefelter, H. F., Jun., Reifenstein, E. C., Jun., and Albright, F. (1942): Syndrome Characterised by Gynaecomastia, Aspermatogenesis without A-Leydigism, and Increased Excretion of Follicle-Stimulating Hormone. Journal of Clinical Endocrinology, 2, 615.

Klinefelter, H. F., Jun., Albright, F., and Griswold, G. C. (1943): Experience with a Quantitative Test for Normal or Decreased Amounts of Follicle Stimulating Hormone in the Urine in Endocrinological Diagnosis. Journal of Clinical Endocrinology, 3, 529.

Knaggs, R. L. (1925): On Osteitis Deformans (Paget's Disease) and its Relation to Osteitis Fibrosa and Osteomalacia. British Journal of Surgery, 13, 206.

KnIEs, P. T., and Le Fever, H. E. (1941): Metabolic Craniopathy: Hyperostosis Frontalis Interna. Annals of Internal Medicine, 14, 1,858. 
KосH, W. (1921): Ueber die russisch-rumänische Kastratensekte der Skopzen. Jena: G. Fischer.

McCullagh, E. P., and Renshaw, J. F. (1934): The Effects of Castration in the Adult Male. Journal of the American Medical Association, 103, 1,140.

McCullagh, E. P., and Rossmiller, H. R. (1941): Methyl Testosterone. 1. Androgenic Effects and the Production of Gynecomastia and Oligospermia. Journal of Clinical Endocrinology, 1, 496.

MARCHAND, L., and BAUER, E. (1925): Epilepsie jacksonienne, acus d'hemiplegie et osteite hypertrophiante due fro tale, probablement de nature-heredosiphilitique. Bulletin de la Société clinique de médecine mentale, 13, 116. Milhorat, A. T., and Toscan,, V. (1939): Studies in Diseases of Muscle. VIII. Metabolism of Calcium, Phosphorus and Magnesium in Progressive Muscular Dystrophy, Myotonia Atrophica and Familial Periodic Paralysis. Archives of Neurology and Psychiatry, 41, 1,130.

MoORE, S. (1935): Hyperostosis Frontalis Interna. A Preliminary Study. Surgery, Gynecology and Obstetrics, 61, 345.

MOORE, S. (1936a): Metabolic Craniopathy. American Journal of Roentgenology, 35, 30.

MoOre, S. (1936b): Calvarial Hyperostosis and the Accompanying Symptom Complex. Archives of Neurology and Psychiatry, 35, 975.

MOORE, S. (1955): Hyperostosis Cranii. Springfield, Illinois: Charles C. Thomas.

MOREL, F. (1930): L'hyperostose frontale interne. Syndrome de l'hyperostose frontale interne avec adipose et troubles cérébraux. Paris: Doin.

MoRgAGN, G. B. (1765): De sedibus et causis morborum. Editio secunda. Liber 1, p. 27. Patavii: Remondiniani. (Opera Omnia, Leyden (1765), 3, 246.)

Narto, I., and SchülleR, A. (1923): Ueber die Hyperostosen des Schädels. Wiener klinische Wochenschrift, 36, 792.

PiCARD, P. (1926): Epaississement Pagetique de crane avec Syndrome De Mentiel. Bulletin de la Société clinique de médecine mentale, 14, 139.

Putnam, T. J., Benedict, E. B., and Teel, H. M. (1929): Studies in Acromegaly. VIII. Experimental Canine Acromegaly Produced by Injection of Anterior Lobe Pituitary Extract. Archives of Surgery, 18, 1,708.

Robinson, F. J., Power, M. H., and KePler, E. J. (1941): Two New Procedures to Assist in the Recognition and Exclusion of Addison's Disease. A Preliminary Report. Proceedings of the Staff Meetings of the Mayo Clinic, 16, 577.

ROUQUìs, L. (1931): La myotonie atrophique, p. 43. Paris: Amédée Legrand.

SCHARNKe and Full (1920): Innere Sekretion und myotonische Dystrophie. Zeitschrift für die gesamte Neurologie und Psychiatrie, Originalien 61, 146.

SCHIFF, P., and Trelles, J. O. (1932): Hyperostose frontale (syndrome de Stewart-Morel) d'origine traumatique Considérations médico-légales. Annales de Médecine Légale, 12, 10.

SHATtock, S. G. (1913): Morbid Thickening of the Calvaria; and the Reconstruction of Bone Once Abnormal; a Pathological Basis for the Study of the Thickening Observed in Certain Pleistocene Crania. Transactions of the 17th International Congress of Medicine, Section Three. Independent Paper, p, 26. London.

Silberberg, M., and Silberberg, R. (1943): Influence of the Endocrine Glands on Growth and Aging of the Skeleton. Archives of Pathology, 36, 512.

Stewart, R. M. (1928): Localised Cranial Hyperostosis in the Insane. Journal of Neurology and Psychopathology, 8, 321.

Troell, A. (1938): “ Syndroma Morgagni ” hos patienter med samtidig akromegali och tyreotoxikos. Svenska Läkartidningen, 35, 763.

WAGENSEIL, F. (1927): Beiträge zur Kenntnis der Kastrationsfolgen und des Eunuchoidismus bein Mann. Zeitschrift für Morphologie und Anthropologie, 26, 264.

Waring, J. J., RAVIN, A., and WalkeR, C. E., Jun. (1940): Studies in Dystrophia Myotonica. II. Clinical Features and Treatment. Archives of Internal Medicine, 65, 763.

WERNER, S. C. (1943): A Quantitative Study of the Urinary Excretion of Hypophyseal Gonadotropin, Estrogen, and Neutral 17-Ketosteroids of Normal Men. Journal of Clinical Investigation, 22, 395.

Wilson, S. A. K. (1940): Neurology, Vol. 2, p. 1,041. London: Edward Arnold \& Co. 